\title{
Austrian Philosophy and its Institutions: Remarks on the Philosophical Society of the University of Vienna (1888-1938).
}

\author{
DENIS FISETTE \\ Université du Québec à Montréal \\ Fisette.denis@uqam.ca
}

\begin{abstract}
This study examines the place of the Philosophical Society of the University of Vienna (1888-1938) in the evolution of the history of philosophy in Austria up to the establishment of the Vienna Circle in 1929. I will examine three aspects of the relationship between the Austrian members of the Vienna Circle and the Philosophical Society which has been emphasized by several historians of the Vienna Circle: the first aspect concerns the theory of a first Vienna Circle formed mainly by H. Hahn, P. Frank and O. Neurath; the second aspect is the contention that the missing link between the Vienna Circle and the Bolzano tradition in Austria is Alois Höfler, a student of Brentano and Meinong; I will finally examine the link they established between the annexation of the Philosophical Society to the Kant-Gesellschaft in 1927 and the founding of the Vienna Circle in 1929. I will argue that this institution played a key role in the history of philosophy in Austria and is partly responsible for the formation of the Vienna Circle.
\end{abstract}

Deutsche! Wann werdet ihr von einer
Verirrung, welche euch euren Nachbarn nur
ungenießbar und lächerlich macht, endlich
zurückehren?
B. BOLZANO

Und auch dieser Ruf des edlen Philosophen verdient, noch in unsere Zeit gehört zu werden!

J. C. KREIBIG

Many studies on the history of Austrian philosophy are dominated by the idea of a specifically Austrian philosophy (or Austro-Hungarian), whose origins date back to the Prague philosopher Bernard Bolzano, and whereby the focus is placed on Brentano's philosophy and his student's original contributions to this research program. This idea is at the heart of Otto Neurath's book published in French in 1935 under the title Le développement du Cercle de Vienne et l'avenir de l'empirisme logique, in which he indicates that the philosophy promoted by the Vienna Circle is not only indebted to this

A version of this text served as my presidential address at the 2011 Annual Congress of the Canadian Philosophical Association in Fredericton. Many aspects of my research on the Philosophical Society of the University of Vienna were the subject of conferences delivered at the Universities of Luxemburg, Rio de Janeiro, Grenoble and Ottawa. I wish to thank all of those who took part in the discussions, Kevin Mulligan for his comments on a previous version of this text, and Denis Courville who is responsible for the English translation. I wish to thank as well the Canadian Social Sciences and Humanities Research Council for the financial support provided for this research. 
Austrian philosophical tradition, but can been seen as its culmination. The thesis of a specifically Austrian philosophy has recently been held by Rudolf Haller in a number of studies, most notably in an article entitled "Wittgenstein and Austrian Philosophy", in which he formulates the so-called "Neurath-Haller Thesis". According to this thesis, there is since Bolzano an autonomous Austrian philosophy (particularly with respect to the German tradition) which possesses an "intrinsic homogeneity" that can be characterized among other things by its scientific world view and its aversion for Kantianism and metaphysics.

In recent years, this thesis has given rise to a number of discussions which we will not examine here ${ }^{2}$. We shall focus our efforts on the issue of the empirical circumstances regarding the development of this Austrian Geist up to the foundation of the Vienna Circle in 1929. In other words, we will examine the institutional and cultural factors that have made possible, at a concrete level, the transmission of this tradition. K. Mulligan ${ }^{3}$ and B. Smith ${ }^{4}$ have both recognized the importance of this question and the significance of socio-political, economic, and cultural factors, and more generally of institutions, in the explanation of this phenomenon. But which factors and institutions were specifically at play? Smith does not directly address this question, but refers to the Manifesto of the Vienna Circle in which Neurath, its main author, emphasizes the importance of the Philosophical Society of the University of Vienna (of which Neurath was himself an active member from 1906 to the mid-1920's) ${ }^{5}$. Founded in 1888, the Philosophical Society ceased its activities in 1938, the year that Husserl, one of its most faithful

1. R. Haller (1981, p. 92) formulates this thesis as follows: "I wish [...] to defend two theses: first, that in the last 100 years there has taken place an independent development of a specifically Austrian philosophy, opposed to the philosophical currents of the remainder of the German-speaking world; and secondly that this development can sustain a genetic model which permits us to affirm an intrinsic homogeneity of Austrian philosophy up to the Vienna Circle and its descendants."

2. On this question, see Mulligan's recent article (2011).

3. Mulligan (2001, p. 8) writes on this question: "But the institutional and cultural history of the effects of Bolzano, Brentano and his students remains to be written."

4. Smith (1996, p. 6) recommends a mixed explanation that appeals to institutional factors: "Hence there is a need, in regard to our specific problem of the rise of scientific philosophy in interwar Vienna, to provide a mixed explanation, one that makes room both for institutional and economic and sociopolitical factors of the kind so far considered and also for the serendipitous role of individuals. A forceful and coherent explanation along exactly these lines has been provided by Neurath himself, in the section labeled 'Prehistory' of the Vienna circle manifesto."

5. Cf. O. Neurath, 1935, p. 38 and 1929, p. 302. 
members died. Since its foundation, this organization served as a forum for philosophical discussions which brought together Vienna's major philosophical, scientific and literary figures of the late nineteenth century. More than six hundred conferences were delivered within this society during the fifty years of its existence ${ }^{6}$ and its members were not only for the most part Austrian philosophers from that era, but also many scientists and intellectuals interested in philosophical issues. It is therefore surprising that such a respectable institution has never been the subject of a systematic study ${ }^{7}$. There are however a few studies that have emphasized the importance of this organization's activities for its members, the most well-known and earliest being that of C. Schorske, Fin-de-Siècle Vienna. Politics and Culture, in which he examines the "Klimt Affair", a question we will later return to more in detail ${ }^{8}$.

But these studies provide us only with a limited perspective on the diversity and the richness of the discussions that took place between the Society's members and explain even less the role of this organization in the evolution of ideas during this decisive period in the history of philosophy in Austria. For want of describing in detail the proponents and the accomplishments of this organization, we will predominantly

6. R. Meister (1938) has drawn up a list of the conferences and discussions that marked the history of the Philosophical Society during the 50 years of its existence.

7. Cf. J. Blackmore (2001, p. 74) offers the following explanation: "We are only at the start of a serious research into the Vienna Philosophical Society and there are many more basic documents and publications which still must be found in order to really understand this remarkable organization and how it could have slipped out of scholarly attention so completely." Thanks to the technological resources that are presently at our disposal, we now have access to most documents relating to the Philosophical Society. Cf. bibliography.

8. In addition to a study written by Schorske (1980), let us mention the edition of a portion of Otto Weininger's correspondence by H. Rodlauer (1990). Rodlauer has shown that the discussions within the Society have directly contributed to the philosophical and scientific education of the young Weininger and to the development of his classical work, Geschlecht und Charakter. We should also mention the studies written by J. Blackmore (1995, 2001a and 2001b) on Mach and Boltzmann, in which he insists on several occasions on the importance of the Society for this segment of the history of philosophy in Vienna. More recently, T. Uebel (2000) has insisted on the importance of the discussions in the Philosophical Society regarding the philosophical education of the Austrian members of the Vienna Circle, particularly that of Otto Neurath, to which we will return later. Breuer's biographer, A. Hirschmüller (1978), has also discussed Breuer's active participation in the Society's activities and has published part of his correspondence with Brentano regarding the famous dispute on Darwinism, which Rodlauer also discusses. D. R. Coen (2007) has examined another debate within the Philosophical Society about Adolf Exner's rectorial address which gave rise to Brentano's well-known article "Über die Zukunft der Philosophie" and in which A. Höfler, W. Jerusalem and F. Jodl also took part. Recently, in a book entitled The Schenker Project, N. Cook (2007) has offered a commentary of Heinrich Schenker's conference (February 15 and March 18, 1895) entitled "Der Geist der Musikalischen Technik". 
focus on the importance of the Philosophical Society in the genesis and prehistory of the Vienna Circle. We will examine three aspects that characterize the relationship between the members of the Vienna Circle and the Philosophical Society. The first aspect deals with the thesis of a proto-Vienna Circle; the second concerns the missing link thesis connecting the Vienna Circle with the philosophical tradition of Bolzano and Brentano in Austria; and lastly, the third corresponds to the connection established by many historians of logical empiricism between the Philosophical Society's annexation to the KantGesellschaft in 1927 and the foundation of the Vienna Circle in 1929.

\section{The Characteristic Features of the Philosophical Society of the University of Vienna}

Let us start with a brief description of the Philosophical Society of the University of Vienna. Thanks to the testimony of some of the Society's members and especially its annual reports ${ }^{9}$, we possess a great deal of valuable information concerning its origins, its structure, its activities and the characteristic features that distinguish it from other societies, for which most Viennese of that time expressed a predilection. We know first of all that the Philosophical Society was officially founded on March 26, 1888 by students of Franz Brentano. One of these students, who contributed to its creation, was the Polish philosopher Kazimir Twardowski who recounts in his autobiography the circumstances under which the Society was founded. Twardowski mentions, in addition to the informal seminars held by Brentano at the University Vienna, the creation of a discussion group comprised of some of Brentano's students:

But my philosophical study was not exhausted by attending lectures and seminars and by the solitary reading of philosophical writings, among which the works of the British philosophers were at the forefront. It also found valuable nourishment and maturation from a group reading (together with a number of similarly disposed philosophy students) of the major works of Aristotle. This philosophical reading club was formed on the initiative of Dr. Hans Schmidkunz, later well known in wide circles as the author of philosophical books and champion of higher-school pedagogy, to whom a lasting friendship binds me ever since those University years. Dr. Schmidkunz not only launched that reading club, in which we delved deeply - in the spirit of Brentano - into the reading

9. The annual reports of the Philosophical Society were published from 1888 to 1918 under the title "Jahresbericht der philosophischen Gesellschaft an der Universität zu Wien" (= Jahresbericht). 
and interpretation of Aristotle's original text (with the aid of Thomas Aquinas commentary), but also managed to initiate regular meetings devoted to philosophical exchange between the veterans and the beginners from among Brentano's students, which not only brought the individual participants personally closer together, but also led to the inauguration in 1888, likewise due to the impetus of Dr. Schmidkunz, of the Philosophical Society at the University of Vienna. I was rather proud to be elected the first Vice-President of that Society. My close relations to Alois Höfler, J[osef] Clemens Kreibig and Christian von Ehrenfels to mention those names that are of philosophical interest, go back to that time ${ }^{10}$.

K. Twardowski, H. Schmidkunz, J. C. Kreibig, C. von Ehrenfels and A. Höfler were indeed very active during the first thirty years of the Philosophical Society's existence and most of them held key positions in the administration of this organization. Höfler was appointed as the first president of the Society and held this position at two different occasions, as we shall see later. The list of the Society's members, updated in each of the annual reports, mentions the names of many other students of Brentano, most notably: A. Meinong and most of his students from Graz; Husserl, who was studying since 1886 under the supervision of Carl Stumpf in Halle; Franz Hillebrand, a student of Marty, E. Heiring and E. Mach in Prague; and many other lesser-known students such as Richard Wahle, Karl Neisser, Georg C. Fulda, Eduard Leisching and Alfred von Berger, just to name a few. Most of Brentano's students held the majority of positions in the Austrian universities, while others held administrative functions, such as E. Leisching, the director of an art museum ${ }^{11}$, K. Neisser, who was a librarian, and the flamboyant Alfred von Berger who is known for having been director the Burgtheater of Vienna ${ }^{12}$. Like most of his students, Brentano was heavily involved in the activities of the Society and gave the inaugural address entitled "On the Method of Historical Research in the Discipline of Philosophy"13, a conference known for characterizing as pathological the system-building efforts of the German idealists. He will deliver again five other

10. Twardowski, 1999, p. 21; cf. Jahresberichte 1897-1898 and 1912-1913 on the circumstances surrounding the foundation of the Philosophical Society.

11. Cf. E. Leisching, 1978.

12. Cf. A. Bettelheim, 1915.

13. Brentano, 1888. 
conferences before leaving Austria for Switzerland in 1895; most notably one on the concept of truth ${ }^{14}$ and another one on the future of philosophy ${ }^{15}$.

That being said, despite the involvement of Brentano and his students in this organization, the initial vocation of this society was not aimed at promoting the interests of a particular group, nor a specific cause, which was the case with other important associations at the time, such as the Volksbildungsverein, the Ethical Society or even the Vienna Psychoanalytic Society. As a society of the University of Vienna, it depended directly upon the support of the Faculty of Philosophy and its professors. In this respect, we need to remember that Brentano's academic situation as a privatdozent since 1880 and his strained relationship with the state deprived him of any academic power. As such, Brentano's assistance to his students' initiative in founding the club came mostly in the form of moral support. The academic support came rather from Robert Zimmerman, who was since the resignation of Brentano the only full professor within the Department of Philosophy and who held the position of rector at the University of Vienna the year the Philosophical Society was founded. Many of the Society's annual reports emphasize Zimmerman's major contributions to the Society ${ }^{16}$ : not only was he responsible for the Society's institutional foundation, but he was also very active within the organization and presided over it for nearly a decade (from 1889 up to his death in 1898). Two annual reports inform us of the existence of tensions between, on the one hand, Zimmerman and, on the other, Brentano and his students. The origin of the conflict lied in Zimmerman's bias towards Herbart's philosophy and his desire to instill it in the Philosophical Society ${ }^{17}$. This in all likelihood would explain Höfler's resignation as the president of the Society only three semesters after its foundation.

Much like Brentano, Zimmerman had recognized very well the potential of this select club for the future of philosophy in Austria. In one of his many articles on the history of philosophy in Austria, "Philosophie und Philosophen in Österreich" published in 1889 , Zimmerman already recognized in this young society "the organ" of a generation

14. Brentano, 1889.

15. Brentano, 1893. I examine (in Fisette, 2012, forthcoming) the issue of the involvement of Brentano and his students in the Philosophical Society.

16. Jahresbericht, 1897-1898, p. 3; cf. Jahresbericht 1888, p. 5-6, Jahresbericht 1888-1889, p. 5.

17. Jahresbericht, 1893-1894, p. 12 and Jahresbericht, 1912-1913, p. 6. 
of researchers in philosophy and in the sciences, who under the influence of philosophers such as A. Comte and J.S. Mill, endorsed empiricist principles. ${ }^{18}$. As a student of Bolzano and a proponent of the philosophy of Herbart, Zimmerman's claim is significant. It allows us indeed to identify a dominant orientation in the history of philosophy in Austria, stretching from Bolzano to the Vienna Circle, and including Herbartianism, which dominated the history of philosophy in Austria for a number of years, the School of Brentano and a few other members of the Philosophical Society such as T. Meynert and other students of Brentano mentioned by Zimmerman in this article. This empiricist orientation, by which Zimmerman characterizes the philosophical position common to all of the Philosophical Society's founding members, is indeed the common denominator of the history of the Philosophical Society up to the Vienna Circle. This tendency expresses itself most notably with respect to its members' predilection for British empiricism, as it is shown in many conferences and discussions on this topic. This has also been noticed by Neurath in the historical portion of his book, in which logical empiricism appears to be the culmination of these empiricist orientations expressed within the history of Austrian philosophy since Bolzano. As the first sentence of the book explains, Vienna centralizes "the conditions conducive to the development of an empiricist attitude such as the one radically professed by the Circle" ${ }^{\prime 19}$. In a speech delivered on the occasion of his $70^{\text {th }}$ birthday, Zimmerman states that this empiricist tendency was originally a reaction to the decline of speculative systems and particularly German idealism ${ }^{20}$. Brentano's philosophy of history upheld by most of his students is also based on the same assessment.

Zimmerman's remark on the involvement of researchers from the natural sciences in the Philosophical Society introduces another important characteristic feature of this institution, namely its interdisciplinary vocation. This is ascertained by the membership list and the conferences delivered at the Society during the first years of its existence. We can observe that not only professional philosophers did not constitute the majority of the Society's membership, but also that the founding members of the Society, who belonged

18. Zimmermann, 1889, p. 269.

19. Neurath, 1935 , p. 8.

20. Jahresbericht, 1893-1894, p. 4-13. 
to other departments in the Faculty of Philosophy, were indeed very involved in the organization and the activities of the Society. Zimmerman mentions rightly so the contribution of T. Meynert ${ }^{21}$, a student of Rokitansky, who was himself a student of Bolzano. But we should also call attention to the involvement of many of Meynert's colleagues from the Department of Medicine, such as J. Breuer, Brentano's medical doctor and a collaborator of his student Freud, M. Benedikt, H. Obersteiner and M. Kassowitz. Zimmerman mentions as well Theodor Gomperz from the Department of Philology who, with his son Heinrich, is the cause behind Mach's hiring at the University of Vienna ${ }^{22}$. But the list does not end there. Indeed, many other well-known scientists were also active in the Society, notably members of the Department of Physics, such as Franz Exner and his Circle ${ }^{23}$, L. Boltzmann, S. Meyer, M. Smoluchowski, F. Hasenöhrl and P. Frank; the representatives of the Viennese School of art history: F. Wickhoff, A. Riegl and M. Dvorak; the famous Austrian economists Carl Menger, Josef Schumpeter and Ludwig Bertalanffi; lastly, some of the professors of the Department of Mathematics, among them Hans Hahn, and the Department of Musicology, such as G. Adler.

That being said, this society was not solely the organ of the Faculty of Philosophy and, contrary to other organizations, it was not reserved exclusively to its members. Since its creation, this society attributed to itself a democratic vocation, a principle often emphasized in many of its annual reports ${ }^{24}$ and which translated itself concretely into what was called at the time in England "University extension" European movement that spread to Vienna in the 1880's with the establishment of the Volksbildungsverein [Circle of Popular Education] in which many of the members of the Philosophical Society were involved, including Ludo Hartmann, E. Reich, T. Leisching, T. Meynert, A. Lampa, F. Jodl and W. Jerusalem. But whereas the vocation of the Volksbildungsverein lied in promoting scientific education to those who did not have access to it, the idea behind the expansion of the university was to extend and to democratize the activities of the teaching staff outside of the academic sphere and to

21. Cf. Höfler, 1892.

22. Cf. J. Mayerhofer, 1967.

23. Cf. B. Kralik and E. Schmid, 1982, and D. R. Coen, 2007.

24. Cf. Jahresbericht, 1896-1897, p. 2.

25. Cf. M. Keilhacker, 1929. 
make them accessible to the general public. Brentano's seminars, which led to the foundation of the Philosophical Society, represent an example of this movement. This explains for example that the membership of the Philosophical Society does not accurately reflect the number of audience members who regularly participated in the Society's meetings. The 1902-1903 Annual Report lists between 200 and 300 attendees, yet we know for a fact that a conference given by Jerusalem in 1904 attracted more than 800 people $^{26}$.

Another distinctive feature of this society is the importance given to discussions during its meetings. The way in which discussions were conducted imposed itself not long after the Society's creation and it replaced the initial formula whereby discussions were to be limited only to parallel meetings on texts and topics determined beforehand. The new formula simply consisted in introducing the discussion topic with a short presentation and in confronting the point of views:

These [discussions] (conducted for the most part by Höfler and by Kreibig during Höfler's four year absence in Vienna) are and were dedicated to the free exchange of ideas on all sorts of contentious philosophical problems that were usually of a more general nature; following the presentation of a very detailed issue by the commentators, and even if the discussions were spontaneously conducted without any particular preparation on the part of the other participants, they led nevertheless in most cases to the preferred option of reconciling the contradictory positions or at least to a clarification of the point of views required by all parties ${ }^{27}$.

We know as well that these discussions continued most of the time at the "Kaiserhof" Café or the Mitzko Café near the University as indicated by many documents which even specify that most of the discussions simply did not go through the University $^{28}$.

The choice of discussion topics was determined by the commission and could be related to one of the Society's conferences, a recent work or even an event of general

26. Cf. W. Jerusalem, 1925, p. 32.

27. Jahresbericht, 1913, p. 8-9.

28. Every member of the Society received before each meeting an invitation (Einladung), on which appeared the agenda, the title of the conference as well as an invitation to the members and their guests to take part in the evening discussion meetings that were held regularly at the Café Mitzko. 
interest. The most well-known case is the "Klimt Affair". To make a long story short, the University of Vienna had ordered a painting from the painter Gustav Klimt intended for the new building housing the Faculty of Philosophy. Klimt produced a large mural entitled "Philosophy", which did not please the members of the Faculty, so much so that the latter signed a petition to have it removed. The art historian Franz Wickhoff resented his colleagues' haste in passing so rashly a categorical judgment in the absence of any competence in the matter. In fact, Wickhoff delivered a conference "Was ist häßlich?" [What is Ugly?] in front of a large audience in the course of which he defended Klimt ${ }^{29}$. An annual report referred to Wickhoff's conference to show that the Society represented the forum where questions regarding current events were discussed philosophically at the time:

Let us first take the example of F. Wickhoff's conference "What is Ugly?" and the discussions that resulted from the following general meeting of the Society. During this period, since all of Vienna was held in suspense by a particular artistic question, our Society proved to be a place where each question, in spite of it being a current event, could be treated with serene objectivity on the basis of documents provided by art history and, it would seem, to the satisfaction of all those who took part in the conferences and the discussions ${ }^{30}$.

A final characteristic feature of the Society should be mentioned, namely its involvement in the publication and the edition of philosophical works. Indeed, in addition to the annual reports published between 1888 and 1917 and in which we find the list of the conferences and the discussions, the membership list, the purchases of the library and its financial statements, the Society also published a selection of conferences and discussions in the proceedings which took on many names over the years ${ }^{31}$. In 1914, the Philosophical Society established the Bolzano Commission, whose mandate was to

29. Cf. H. Bahr, 1903 and A. Strobl, 1964.

30. Jahresbericht, 1899-1900, p. 1.

31. Between 1902 and 1911, the title of this publication was "Wissenschaftliche Beilage zum Jahresbericht der philosophischen Gesellschaft an der Universität zu Wien"; it was changed in 1912 for "Jahrbuch der philosophischen Gesellschaft an der Universität zu Wien", a title which remained until 1916. After a ten-year interruption, it was published between 1926 and 1935 under the title "Wissenschaftliche Jahresberichte". The Philosophical Society has also published works under the title "Veröffentlichungen der Philosophischen Gesellschaft an der Universität zu Wien": J. Reynolds (1893), A. Höfler (1899), I. Kant (1900) and A. Höfler (1900). 
prepare the edition of Bolzano's complete works, including the manuscripts discovered in Zimmerman's archives. But only Bolzano's Paradoxes of the Infinite and the first two volumes of his Wissenschaftslehre were published by the Society ${ }^{32}$. We will later return to this topic.

\section{The Proto-Vienna Circle and the Philosophical Society}

With this concise description of the Philosophical Society of the University of Vienna, we may now address the question of its significance in the history of philosophy in Austria and its key role in the prehistory of the Vienna Circle. Neurath emphasized on two occasions the Philosophical Society's importance in the prehistory of the Vienna Circle: the first one in the Vienna Circle Manifesto in which he insists on the importance of the numerous discussions on the foundations of physics and other problems relating to the logic and theory of knowledge ${ }^{33}$; he refers to it a second time in his 1935 book where he specifies on this occasion that the discussions that took place in the Society triggered a long process whereby the Vienna Circle was established:

In Vienna, the logical tendency of the Brentano School was professed by a man who, by launching discussions on the foundations of physics, triggered the beginnings of the Vienna Circle at the onset of the $20^{\text {th }}$ century: Alois Höfler, Professor of Pedagogy at the University of Vienna. He was, for a long time, responsible for the publications of the "Philosophical Society of the University of Vienna"; these publications reveal a dedication in confronting the same problems to which the Vienna School would later dedicate itself ${ }^{34}$.

32. Cf. B. Bolzano, 1914 and 1920.

33. "Brentano and his students time and again showed their understanding of men like Bolzano (Wissenschaftslehre, 1837) and others who were working toward a rigorous new foundation of logic. In particular Alois Höfler (1853-1922) put this side of Brentano's philosophy in the foreground before a forum in which, through Mach's and Boltzmann's influence, the adherents of the scientific world conception were strongly represented. In the Philosophical Society at the University of Vienna numerous discussions took place under Höfler's direction, concerning questions of the foundation of physics and allied epistemological and logical problems. The Philosophical Society published Prefaces and Introductions to Classical Works on Mechanics (1899), as well as the individual papers of Bolzano (edited by Höfler and Hahn, 1914 and 1921). In Brentano's Viennese circle there was the young Alexius von Meinong (1870-82, later professor in Graz), whose theory of objects (1907) has certainly some affinity to modern theories of concepts and whose pupil Ernst Mally (Graz) also worked in the field of logistics. The early writings of Hans Pichler (1909) also belong to these circles" (Manifesto, 1929, p. 303).

34. Neurath, 1935, p. 38. 
The reference to Höfler in this passage aims at establishing a certain continuity between the Vienna Circle and the philosophical program supported by Brentano and his students as well as to distinguish within the Society's history the periods chaired by Höfler from those chaired by other members of the Society such as F. Jodl (1903-1912) and Reininger (1922-1938), to whom will return shortly. It is indeed during Höfler's term as the Society's president that the discussions referred to by Neurath were the most significant.

\subsection{Haller's Thesis on the Proto-Circle and Frank's Testimony}

While Neurath simply focused on the filiation between logical empiricism and empiricist tendencies within Austrian philosophy, other historians have put forward the idea that there was, among the members of the Philosophical Society, a group that constituted what R. Haller has called the first Vienna Circle:

The thesis I present for examination is this. Even before the founding of the so-called Vienna Circle around Moritz Schlick, there existed a first Vienna Circle with Hans Hahn, Philipp Frank and Otto Neurath. This circle is of such constitutive importance for the formation of the circle around Schlick that the judgment can be justified that it was really Hans Hahn who founded the Vienna Circle. To draw attention to this I call the one the first, the other the second Vienna Circle $^{35}$.

This thesis has been reiterated and developed systematically by other historians of Austrian philosophy, particularly F. Stadler and especially T. Uebel ${ }^{36}$. This thesis is based on a remark made by Philipp Frank in the introduction to his book Modern Science and its Philosophy, where he alludes to the existence of a discussion group that met in Vienna in the 1900's and whose most active members were himself, Hahn and Neurath:

At the time when the first chapter of this book was written (1907) I had just graduated from the University of Vienna as a doctor of philosophy in physics. But the domain of my most intensive interest was the philosophy of science. I used to associate with a group of students who assembled every Thursday night in one of the old Viennese coffee houses. We stayed until midnight and even later, discussing problems of science

35. Haller, 1991, p. 95.

36. Cf. T. Uebel, 2000, p. 76 sq. 
and philosophy. Our interest was spread widely over many fields, but we returned again and again to our central problem: How can we avoid the traditional ambiguity and obscurity of philosophy? How can we bring about the closest possible rapprochement between philosophy and science? By "science" we did not mean "natural science" only, but we included always social studies and the humanities. The most active and regular members of our group were, besides myself, the mathematician Hans Hahn, and the economist, Otto Neurath ${ }^{37}$.

Frank informs us also that Hahn, Neurath and himself did not only take interest in the Grenzfragen regarding their respective fields, but that they also strived in these discussions "to absorb as much information, methodology and background from other fields as we were able to get $^{38}$ ". There is reason to believe that the discussions that fueled these famous meetings were not unrelated to the Philosophical Society's activities, to which Franck as a physicist, Neurath as an economist and Hahn as a mathematician owed much of their philosophical instruction. This is initially confirmed at the beginning of Franck's first conference in 1907 at the Philosophical Society entitled "Mechanismus oder Vitalismus?": “The Philosophical Society was always the place where the representatives of different scientific fields met to discuss the boundary questions of their respective disciplines ${ }^{39}$.",

Another passage in the introduction to his 1949 book indicates that Hahn, Neurath and Franck were not the only members of this group, but also that their discussions addressed topics that were for the most part remote from their academic concerns:

This apparent internal discrepancy provided us, however, with a certain breadth of approach by which we were able to have helpful discussions with followers of various philosophical opinions. Among the participants in our discussions were, for instance, several advocates of Catholic philosophy. Some of them were Thomists, some were rather adherents of a romantic mysticism. Discussions about the Old and New Testaments, the Jewish Talmud, St. Augustine, and the medieval schoolmen were frequent in our group. Otto Neurath even enrolled for one year in the Divinity School of the University in order to get an adequate picture of Catholic philosophy, and won an

37. Frank, 1949, p. 1.

38. Frank, 1949, p. 1.

39. Frank, 1908, p. 393. 
award for the best paper on moral theology. This shows the high degree of our interest in the cultural background of philosophic theories and our belief in the necessity of an open mind which would enable us to discuss our problems with people of divergent opinions $^{40}$.

For the moment, we will abstain from identifying the other members of the group in question, but it is very likely that they are for the most part members who regularly participated in the activities of the group during the period referred to by Frank ${ }^{41}$.

There are other reasons to think that the discussions within this group were fueled by the activities of the Philosophical Society. First, we should remember that Hahn like Victor Kraft, who arguably belonged to this group, became members of the Society as soon as 1901, followed by Frank (1903), Neurath (1906), Olga Hahn (1908) and Edgard Zilsel (1913). They delivered many conferences within the Society and all took part actively in the discussions ${ }^{42}$. Hahn, Franck and Kraft were all involved in the administration of the Society: in 1899, Kraft contributed to the edition, prepared by the Philosophical Society, of Kant's work Metaphysische Anfangsgründe der Naturwissenschaft; Hahn contributed to the edition of The Paradoxes of the Infinite, while Franck was in 1911 the Society's secretary ${ }^{43}$. It should be mentioned finally that P. Frank and H. Hahn remained members of the Philosophical Society even after having left Vienna. It is therefore very likely that these Thursday meetings to which Frank refers in his introduction coincided most of the time with the Society's activities and focused on the organization's conferences and discussions. Thus, the arguments raised in support of an initial Vienna Circle seem on the contrary to indicate that the activities of the group in question were inseparable from the activities of the Society and that, if we rely on the testimony offered by Frank, this pseudo Vienna Circle was in fact simply a group

40. Frank, 1949, p. 1-2.

41. Many of the Society members that were active at the time correspond to Frank's description: Hans Pichler, also mentioned by Neurath $(1935$, p. 37), Wolfgang Schultz, who contributed to the edition of Bolzano's works and possibly Hans Von Arnim, T. Gomperz's replacement, Oskar Ewald, Emil Lucka and Robert Eisler. It should be noted that Hahn was also interested in parapsychological phenomena (cf. Karl Menger, 1988).

42. Cf. T. Uebel, 2000, p. 140-142.

43. One of the Society's annual reports (Jahresbericht 1911-1912, p. 2) mentions Frank's significant contribution to the Society as well as his involvement as a speaker and a member responsible for discussions pertaining to philosophical problems in physics. 
comprised of a few members of the Philosophical Society who mainly discussed various questions that stemmed from the organization's activities.

\section{The Missing Link and the Reception of Bolzano in Austria}

Let us now come back to the more general question of the Philosophical Society's role in the history of philosophy in Austria up to the foundation of the Vienna Circle in 1929. By relying on the diagnostic made by Neurath in his 1935 book, Uebel (1999, p. 259) argued that the missing link connecting the Austrian tradition, represented by Bolzano and Brentano, with the Vienna Circle was no one other than Höfler himself. This argument was systematically developed in his voluminous work on Neurath, in which he formulates his argument as follows:

In the work and person of Höfler met the Austrian philosophical tradition and modern philosophical Vienna. This is suggested by a closer examination of both aspects of Höfler's influence, which had a special meaning for the first Vienna Circle ${ }^{44}$.

This thesis has also been supported more or less explicitly by J. Blackmore in his book on Boltzmann, in which he emphasizes Höfler's role in this history so much so that he speaks of Höfler's Society ${ }^{45}$. At first glance, this thesis may seem plausible notably because of the key positions held by Höfler in the Society since its foundation. Indeed, he led the discussions for more than twenty years, he was president on three occasions (1888, 1898-1903, and 1913-1922) and he received the title of honorary president [Ehrenpräsident] when he left for Prague in 1903. Moreover, this student of Boltzmann and Stefan already possessed a solid education in the fields of physics and mathematics, and his diverse philosophical interests made him an indispensable intermediate in the discussions between scientists and non-scientists. And as a student of Brentano and especially of Meinong, he maintained privileged ties with many of the Society's members, particularly Kreibig, Schmidkunz, von Ehrenfels and K. Twardowski who, as we have shown, were all very involved in its administration and its activities.

That being said, other indications contradict Uebel's thesis and question the disproportionate importance given to Höfler in the Philosophical Society and, more

44. T. Uebel, 2000, p. 104.

45. Cf. J. Blackmore and al., $2001 \mathrm{~b}$. 
generally, in the transmission of Brentano's and Bolzano's ideas. Ample information contained in his autobiography seems to indicate for example that, despite his academic interest for the Grenzfragen of philosophy and the natural sciences, Höfler was far from sharing the scientific world view of the positivists as well as their aversion for Kantianism and metaphysics. Regarding the question of his relationship to Kantianism, a passage in his autobiography clearly indicates that he did not share Brentano's philosophy of history and his assessment of the philosophy of Kant and Schopenhauer:

Thus when I heard Brentano speak with contempt about Kant and Schopenhauer and jest about Wagner, it was not so much my understanding but my spirit that guarded me from his so-called world view entirely different from divine and human affairs ${ }^{46}$.

How can this full pledged member of the Kant-Gesellschaft, who always defended a Wagnerian world view as indicated in his later writings, most notably on Schopenhauer ${ }^{47}$, represent the Austrian philosophical tradition and act as the missing link between Bolzano and the Vienna Circle? Moreover, considering that Boltzmann and especially Mach held a special significance for the members of the Vienna Circle, we must remember that Höfler, in one his biographical texts on Brentano, criticized the Faculty's decision to hire Mach, who never defined himself as a philosopher, and "Boltzmann, the neophyte in philosophy" who was in reality rejecting it ${ }^{48}$.

The supporters of the missing link thesis would undoubtedly respond to these objections by arguing that Höfler's philosophical allegiance has never stopped him from playing a key role in the transmission of Brentano's ideas and particularly those of Bolzano to the Austrian members of the Vienna Circle. Against Uebel ${ }^{49}$ and Blackmore, we would like to show very briefly, with respect to the example of Bolzano's reception in

46. A. Höfler, 1921, p. 120-1.

47. Cf. A. Höfler, 1920 , p. 89

48. A. Höfler, 1917, p. 325.

49. Uebel (1999) supports the missing link thesis by referring to a few arguments, notably Höfler's role in transmission of Bolzano's ideas to the Austrian members of the Vienna Circle. The first, on which we will focus here, insists on the importance of the textbooks written by Höfler for the teaching of philosophy in Austrian lyceums, notably the Logik of 1890 (written in collaboration with Meinong) which was the source of a lively controversy with Brentano (cf. Höfler, 1921). Uebel argues that it is by means of this textbook that Hahn and Neurath, for example, became acquainted with Bolzano (T. Uebel, 1999, p. 261; cf. also Uebel, 2000, p. 109 sq.) It seems to us that this argument exaggerates the importance of this textbook with respect to education and particularly its Bolzanian content. We will grant more importance to another one of Uebel's arguments which asserts Höfler's role in the reception of Bolzano within the Philosophical Society and Austria. 
Austria, that Höfler's role in this history is marginal in comparison to the one played by many other members of the Philosophical Society and that the problem with the missing link thesis is that we must not let the trees hide the forest. In other words, the connection between the Austrian philosophical tradition and the Vienna Circle is made possible not by an individual, but by an institution.

\subsection{The Reception of Bolzano in Austria}

On March 9 1914, the Philosophical Society sets up the Bolzano Commission, whose primary mandate, according to its statutes and rules, is mainly to ensure the reprinting of Bolzano's works and to publish the manuscripts discovered a few years before $^{50}$. A few months earlier, during the first session of the Philosophical Society in 1913, Höfler presents with great pomp this commission's project in front of many of his faculty colleagues and members of the Society ${ }^{51}$, and recounts the stages that marked the history of this project. He quotes at the outset the 1902-1903 Annual Report that accounts for the discovery of Bolzano's manuscripts, including his function theory, that were for a long time in Zimmerman's possession:

After many unsuccessful attempts [...], a very important collection of Bolzano's original manuscripts which consisted of philosophical writings and mostly mathematical writings were discovered in the Imperial Court Library. The Society's secretary, Robert von Sterneck, examined these muddled manuscripts and we can now value the importance of this discovery. What has been discovered is nothing less than a manuscript on the "theory of functions" which was ready to be printed and is astonishingly close to the modern ideas $^{52}$.

Following this discovery made by von Sterneck, Höfler made a few attempts to obtain the necessary funding to publish Bolzano's works, but these attempts failed particularly due to the fact that Höfler left Vienna and accepted in 1903 a position in

50. The statutes and the rules of the Bolzano Commission are recorded in a document approved on March 9, 1914 entitled "Soderstatut der Bolzano-Kommission der philosophischen Gesellschaft an der Universität zu Wien".

51. Cf. Jahresbericht, 1912-1913, p. 10.

52. Jahresbericht, 1912-1913, p. 6-7. 
Prague $^{53}$. The discovery of Bolzano's manuscripts is indeed an important chapter in the history of Bolzano's reception in Austria, but it is not the first, nor the most important. This is shown in another annual report (1902-1903, p. 6) in which Benno Kerry's contributions are highlighted with respect to a series of articles that he published between 1885 and 1891 under the title "Über Anschauung und ihre psychische Verarbeitung" and in which he discusses notably the Bolzanian doctrine of the propositions in themselves ${ }^{54}$. The writings of Kerry exerted a crucial influence not only on Höfler ${ }^{55}$, but also on K. Twardowski, which the latter confirms in his autobiography:

My work Zur Lehre vom Inhalt und Gegenstand der Vorstellungen. Eine psychologische Untersuchungen grew out of these considerations. I endeavored to write it in the spirit of Franz Brentano -and of Bernard Bolzano, whose Wissenschaftslehre I studied with great zeal ever since I was steered to it by Kerry's paper Über Anschuung und ihre psychische Verarbeitung ${ }^{56}$.

In 1894, Husserl writes an essay, known today as "Intentional Objects", in which he discusses Twardowski's work and his interpretation of Bolzano. Two years later, in his 1896 course on logic, Husserl understands (pure) logic in the sense of Bolzano's Wissenschaftslehre. In 1900, he publishes his Prolegomena to Pure Logic in which he claims the rediscovery of Bolzano and uses the latter's Sätze an sich as an antidote to logical psychologism. The follow-up to the story is well-known, and we now know the importance of the debates surrounding psychologism that the publication of Husserl's work generated within and mostly outside of the Society ${ }^{57}$.

53. Marty's correspondence with Brentano gives us reason to believe however that there were other factors that delayed this project, and notably Marty's own opposition to it, as he was sitting on the Commission charged with evaluating the Society's grant application for the funding of this project. In a letter dated February 19, 1905 and addressed to Brentano, Marty reminds the latter that there must be no question to provide Höfler with such an amount and adds that little wickedness which he attributes to a colleague, that Höfler's main interest in this story was to appear on the cover page of Bolzano's complete works, Cf. Gimpl, 1998.

54. Cf. B. Kerry, 1885-1891.

55. Cf. A. Höfler, 1894.

56. Twardowski, 1999, p. 24.

57. On the reception of Bolzano in Austria, a lesser known publication should be mentioned: a special issue of the journal Deutsche Arbeit (1908) that commemorates the $60^{\text {th }}$ anniversary of Bolzano's death (1781-1848) with articles written by two of Brentano's students, H. Bergmann (1908) and E. Utitz (1908); the following year Bergmann publishes his book Das philosophische Werk Bernard Bolzanos (1909). 
This story's subsequent episode is the institutionalization of the Bolzano project in the Philosophical Society in 1914, that is, following Jodl's resignation as president and the return to power of Höfler and his allies. When presenting this commission in front of the members of the Society, Höfler clearly indicates that the commission's vocation was not only to publish Bolzano's complete works, but also to promote the ideas of this "great Austrian philosopher":

If I allowed myself to mention the creation of a Bolzano Commission within the Philosophical Society, it is first and foremost to avoid that this interest for this great Austrian philosopher subsides and to ensure that it fructifies durably [...]. It suffices for the moment to emphasize that the Philosophical Society of the Vienna University, by what it accomplishes for Bolzano's works, now wishes to pay homage to him on behalf of a philosophical society ${ }^{58}$.

The creation of this commission coincides with the new edition of the first volume of Bolzano's Wissenschaftslehre prepared by W. Schulz ${ }^{59}$. And it is not a coincidence if, in 1914, Twardowski delivers two conferences at the Society's Hauptversammlung which served as the basis for one of his most significant philosophical texts, that is, "Functions and Formations" (Funktionen und Gebilde) in which he understands the formations (or intentional contents), following Stumpf and Husserl, on the basis of Bolzano's model of the propositions in themselves ${ }^{60}$. The interest prompted by these two conferences can be measured among other things by the fact that they led to a few discussion meetings at the Society. It is neither a coincidence if another member of the Bolzano Commission, Josef C. Kreibig, published the same year an article on Bolzano in which he emphasizes the importance of the latter in the history of philosophy in Austria ${ }^{61}$. Kreibig suggests, as clearly indicated by the two passages placed as epigraphs to his article, that Bolzano was then what Kant represented and still represents for philosophy in Germany. He states the following on this subject:

58. Jahresbericht, 1912-1913, p. 14.

59. Bolzano, 1914. H. Hahn's edition of The Paradoxes of the Infinite will follow in 1920.

60. We have offered a French edition of this Twardowski text (Fisette and Fréchette, 2007, p. 343385 ) and have translated "Funktionen und Gebilde" by "Fonctions et formations" ("Functions and Formations") following the indications given by Twardowski himself, who borrows these terms from Carl Stumpf.

61. J. C. Kreibig, 1914. 
We have therefore good reasons to believe that the history of philosophy of the past century would have no significant event to report if it were not for Bernard Bolzano, a thinker whose universality, depth and sagacity deserve more admiration at the scientific level than so many glaring poetic thoughts glorified by his contemporaries ${ }^{62}$.

In summary, the Uebel-Blackmore thesis on Höfler's role as the missing link is questionable not only because of Höfler's philosophical positions, but also for the reason that his role in this history is relatively marginal compared to some of the other members of the Society. Here again, it is an institution, in this case the Bolzano Commission, that serves as the connection with the Austrian members of the Vienna Circle, and particularly with Hans Hahn who was a member of this commission. We should bear in mind however that the question of the reception of Bolzano in Austria, and particularly the

different actions carried out by the members of the Philosophical Society with the aim of promoting the work and the ideas of Bolzano, can only make sense in the light of the symbolic value that the author of the Wissenschaftslehre holds in the history of Austrian philosophy. In the following section, we will attempt to show that this is the significance that he had for some of the Austrian members of the Vienna Circle.

\section{The Creation of the Vienna Circle and the Annexation of the Society to the Kant- Gesellschaft}

A third important aspect regarding the relationship between the Philosophical Society and the members of the Vienna Circle pertains to the relationship established by Stadler (1997, p. 248), Uebel (1999, p. 260; 2000, p. 142) and Blackmore (2001b, p. 257258) between the Society's annexation to the Kant-Gesellschaft in 1927 and the creation of the Ernst Mach Verein, and then of the Vienna Circle in 1929. The connection between these two events has been established on the basis of an anti-Kantian attitude that is often attributed to the Austrian members of the Vienna Circle, and their willingness to create an association founded on a philosophical program that reflects the spirit of the Austrian tradition in philosophy. We believe indeed that there is a strong connection between these two events, but we do not believe that the Philosophical

62. Kreibig, 1914, p. 274. 
Society's annexation to the Kant-Gesellschaft represents by itself a sufficient motive to explain both the withdrawal of the Vienna Circle's Austrian members from the Philosophical Society and their willingness to create a distinct group. Other issues must be taken in consideration in order to explain this decision, particularly political and ideological issues which are intimately related to the Austrian tradition in philosophy.

\subsection{Reininger and the Philosophical Society}

One of the important pieces of this puzzle is the philosopher Robert Reininger, who presided over the Philosophical Society after Höfler's death in 1922 until its disbandment in 1938. This appointment occurred in the context of major transformations in the Viennese philosophical landscape which can be compared to those that marked Brentano's departure from Vienna and Mach's appointment the same year, as well as appointment of the anticlerical F. Jodl and his antidote, the theologian, L. Müllner in 1896. After the death of Adolf Stöhr in 1921, the Philosophy Department was left with no full professor. The following year, the Faculty of Philosophy proceeded to hire three new full professors, including Reininger, who already held a position in Vienna, and two German philosophers who were already established, Moritz Schlick and Karl Bühler. The contribution made by Schlick to the philosophy of logical empiricism is well-known, but that of Bühler to the psychology and the philosophy of language is less, and it is important to know that after the death of Brentano, Meinong, Kreibig and Höfler, Bühler is the one who best represented the Brentanian tradition in Vienna ${ }^{63}$. As for Reininger, he is one of the rare students of Zimmermann and as such, he is the exception that proves the rule, as he is one of the rare proponents of Kantianism, as shown by most of his publications that promote the Kantian view of the world ${ }^{64}$.

\subsection{The Annexation of the Society to the Kant-Gesellschaft}

First, we must remember that Reininger became a member of the Philosophical Society at the turn of the twentieth century and that he quickly rose in the ranks of this organization's hierarchy: under the presidency of Jodl, with whom he maintained strong 
ties, he held from 1904 the position of secretary and, from 1906-1912, the position of the Society's vice-president. Thus, his nomination as president of the Philosophical Society in 1922 went without saying as it ensured continuity in the history of the organization. But were we aware that this epigone of Kant would carry out many actions that were detrimental to the Society, of which he himself had not measured all the consequences? For, under the presidency of Reininger, the Society underwent many major transformations that altered most of the characteristic features that we attributed to it at the beginning of this study. Indeed, the list of conferences and discussions held at the society between 1922 and 1938 indicates that Reininger, in practice, abolished the discussion meetings, which, as we saw, represented the cornerstone of this society. The number of conferences given by non-philosophers was considerably reduced, which implied the renouncement of the interdisciplinary vocation of the Society, or at least its democratic nature. Reininger also abandoned projects that were cherished by his predecessors, mainly that of the Bolzano Commission ${ }^{65}$. Actually, the sum of these measures and other actions carried out by Reininger and his students led to a situation whereby this society could no longer be differentiated from many of the other groups affiliated to the Kant-Gesellschaft. The logical step regarding this degenerating phase in the Society's history was its annexation to the Kant-Gesellschaft. This was carried out in 1927 as confirmed by a report published the same year in the Kant-Studien:

On November 18, 1927 was held, under the presidency of Professor Robert Reininger in Vienna, the general meeting of the "Philosophical Society" during which the "Philosophical Society", to the request of the commission, was acknowledged as a local group of the Kantian Society. From now on, it will bear the title of "Philosophical Society of the University of Vienna", local group of the Kantian Society in Vienna ${ }^{66}$.

The same report however also indicates that the administrative board of the Society, which issued this decision, was comprised among others of K. Bühler, M. Schlick and R. Meister, who held Höfler's pedagogy chair since the latter's death. This

65. We can state as proof the publication of the four volumes of Bolzano's Wissenschaftslehre in 1929 by W. Schultz, a former member of the Bolzano Commission; an edition that does not mention the Society by name. Cf. B. Bolzano, 1929.

66. "Bericht", Kant-Studien, 1927, Bd. 32, p. 556. 
means that even if this initiative most likely came from Reininger, he was supported by many members and especially by his three colleagues, Schlick, Bühler and Meister, with whom moreover he maintained ties of friendship ${ }^{67}$. Furthermore, we know that Bühler like Schlick published on a few occasions in the Kant-Studien ${ }^{68}$ and that Schlick, like many other members of the Vienna Circle, regularly delivered conferences at the KantGesellschaft as well as at the Philosophical Society, even following its annexation. Therefore, whether they were involved in the decision that led to the Society's annexation to the Kant-Gesellschaft, Bühler and mostly Schlick had in principle no reason to oppose it.

The same cannot be said of the Austrian members of the Vienna Circle, who had witnessed the golden age of this society in which they were involved for more than twenty years. There is good reason to believe that they did not welcome with indifference the news of the Society's annexation to the Kant-Gesellschaft. Evidence of this is suggested by the fact that Neurath, Hahn, Frank and Zilsel did not deliver one single conference at the Philosophical Society after 1927. Is this all a matter of coincidence? According to the historians of the Vienna Circle mentioned earlier, not only is it not a coincidence, but the Society's annexation would be at the source of Neurath's efforts to establish a discussion group that would be distinct from the Philosophical Society. In his autobiography, Karl Menger reports that Schlick had received with some reservations Neurath's project of founding the Ernst Mach Circle by recalling the existence of the Philosophical Society:

As the academic year [1928-1929] went on and Carnap got more radical, Neurath got more excited and aggressive. When the idea of spreading the new insights uppermost in his mind, Neurath suggested that a society (ein Verein) for the promotion and propagation of a scientific view of the world be founded and named after Mach. 'We have the Philosophical Society', Schlick protested [...]. But Neurath easily convinced Hahn and Carnap that this was not enough. [...] The Verein would start its activities with some public lectures in 1928-1929. Schlick was not altogether happy. But Neurath was on the warpath $^{69}$.

67. Cf. K. Nawratil, 1969.

68. Cf. M. Schlick, 2008, and K. Bühler, 1926, 1933.

69. K. Menger, 2009, p. 81. 
This testimony offered by Menger sheds light particularly on the issue of the disagreement regarding the question as to whether the Philosophical Society still represented a suitable venue for the future members of the Vienna Circle to freely discuss the philosophical issues that were of interest to them at the time. Neurath was convinced that this was not the case, and our thesis is that his reasons were not foreign to his connection to this specifically Austrian philosophical tradition that he puts forth in his 1935 opuscule. This is what we would now like to examine.

\subsection{Reininger's Motives: His Kantian View of the World}

What explains the withdrawal of the members of the Vienna Circle from the Society's activities and Neurath's willingness to create a distinct entity is maybe less the Philosophical Society's annexation to the Kant-Gesellschaft than the motivations behind this turnaround. Indeed, in another report on the Philosophical Society this time published in the Kant-Studien, Reininger explains his motives a little more clearly. The first concerns precisely the very idea of an Austrian philosophy, of which he disputes the existence in the name of a particular pan-Germanic philosophy:

When we had decided, two years ago, to become a local group of the Kantian Society, this decision was born out of the high esteem that we held for the greatest philosophical association in Germany and the aspiration to formally join the great community of all German friends of philosophy. This community has actually always existed: there is not and has never been a specifically Austrian philosophy for which I should account, but only a German philosophy in which we, Austrians, participate ${ }^{70}$.

This is a rather surprising assertion coming from a philosophy historian and a privileged witness to the development of philosophy in Austria. This can be seen as a form of denial on the part of the president of the Philosophical Society, but there is much more to this decision. This is confirmed by the subsequent passage in which Reininger informs us that the Anschlu $\beta$ (the annexation) of the Philosophical Society to the KantGesellschaft was achieved in the name of an ideal that he attributes to all his compatriots:

70. R. Reininger, 1930, p. 16. 
In this respect, the annexation to the Kant-Gesellschaft also held special symbolic significance for us. Of course, philosophy is not a national matter, but concerns humanity as a whole. But for us, Austrians, this close alliance with the greatest association of German philosophers represents more than a simple community of practical work. It is primarily a testimony to our inseparable spiritual and cultural belonging to the German people and therefore not only a simple question of convenience, but more importantly still, it represents a little step on the path of the realization of an ideal that is alive in all Austrians ${ }^{71}$

Reininger does not yet state what this ideal is, but simply asserts that the Society's subordination to an organization that promotes the "great German philosophers" is an expression of a cultural and spiritual belonging to the German people as a whole. But in other writings, notably in his conference in honor of the $200^{\text {th }}$ anniversary of the birth of Kant and in another text published that same year under the title "Kant and the German Culture" 72 , Reininger indicates unequivocally that this ideal is nothing other than the Kantian world view that he attributes to the Großdeutschland, and that the realization of this ideal, of which the Society's Anschlu $\beta$ to the Kant-Gesellschaft constitutes the first step, must necessary be carried out by means of Austria's Anschluß to Germany. It should therefore come as no surprise that Austria's annexation to Germany in 1938 was, for this proponent of the Großdeutschland, the realization of a dream long cherished ${ }^{73}$.

\subsection{Es gibt eine spezifisch österreichische Philosophie}

Although Reininger's remarks are purely ideological and that as such, they serve no historiographical value, we can nevertheless draw a few valuable conclusions from them. First, by establishing an opposition between, on the one hand, the Kantian world view and the Kant-Gesellschaft and, on the other, the Philosophical Society and a specifically Austrian philosophy, Reininger undoubtedly supposes that, for many philosophers that belong to his generation, the Philosophical Society was to philosophy in Austria what the Kant-Gesellschaft represented for the Kantian tradition in Germany. Secondly, the proposition: "es gab und gibt keine spezifisch österreichische Philosophie"

71. R. Reininger, 1930, p. 16.

72. Cf. R. Reininger, 1924.

73. Cf. K. Nawratil, 1969, p. 69-70. 
does not only follow from positing the existence of a pan-German Kantian philosophy, but also aims to discredit the dominant philosophical tendencies in Austria since Bolzano, as well as the many initiatives carried out to promote these ideas within this respectful institution. The Bolzano Commission is exemplary in this respect. Neurath's initiatives as well as his remarks on the prehistory of the Vienna Circle are specific reactions and responses to these actions carried out in the name of Kantian world view. This is also the case for most of the historical writings of the Society's members following its annexation to the Kant-Gesellschaft. For want of demonstrating this, we will restrict ourselves to a number of general remarks that go in this direction.

In the preface of his book Between Physics and Philosophy, P. Frank also opposes the Austrian philosophical tradition to the Kantian world view of German philosophy, which seems to echo the ideology conveyed by Reininger and his acolytes:

The European movement had its origin in the ideas of the Austrian physicist Ernst Mach. At the beginning of the twentieth century it had a large following in the scientific circles of Austria, especially in Vienna and Prague. In spite of the common German language, this movement could find only a few adherents in the universities of the German Reich, because there the philosophy of Kant and his metaphysical successors reigned, being regarded as a world picture particularly suited to the German nation ${ }^{74}$.

In all of the historical writings of the Austrian members of the Vienna Circle, including those of V. Kraft, we find this twofold concern which consists of distinguishing oneself from this Kantian world view and asserting a connection to the Austrian philosophical tradition. And as Neurath recalls (1935, p. 38), the Kantianism advocated by Reininger is a late option that appears in the history of philosophy in Austria. Neurath's remarks are confirmed by two long-standing members of the Philosophical Society, who serve as privileged witnesses to the evolution of philosophy in Austria after the death of Zimmerman, that is, Heinrich Gomperz and Carl Siegel, who both wrote a short history of philosophy in Austria. Siegel, a student of Jodl who latterly converted to idealism, and of whom we will not therefore accuse of "Kant-bashing", does not hesitate to speak of a specifically Austrian philosophy whose characteristic feature since Bolzano

74. P. Frank, 1941, p. 6. 
is objectivism ${ }^{75}$. Gomperz is less categorical than Siegel or Neurath, but he does ask the right question in an article in which he recounts the history of philosophy in Austria during the years of the Philosophical Society's existence:

It is not easy to say whether any common and specifically "Austrian" features may be detected in all these approaches. What is clear, however, is that a perpetual exchange of ideas as well as of persons has been going on between Austria and the rest of Germany and that, if Austria has been richly fertilized by the great currents of German intellectual life, it has amply repaid its debt by itself contributing to these currents in a measure that ought never to be overlooked ${ }^{76}$.

The general diagnostic offered here by Gomperz reflects the one found in most of the historical writings from Zimmerman up to Neurath, that is, the empirical orientation that is specific to this tradition. This is as well the diagnostic offered by Victor Kraft in his account of the history of the Vienna Circle:

Thus there has existed a long tradition of empiricist philosophy in Vienna, concerned primarily with the natural sciences. But even before that time empiricist tendencies had in a sense asserted themselves through Franz Brentano ${ }^{77}$.

According to this perspective, logical empiricism can be understood as the natural development of this Austrian philosophical tradition, which it also radicalizes as Neurath explains in his 1935 book.

\section{Final Remarks}

One of the objectives of this study was to examine the role of our institutions in the transmission of a tradition during a given period. We have insisted more particularly on the importance of the Philosophical Society of the University of Vienna in transmitting and preserving this typically Austrian tradition in philosophy, and we have shown that it is partly responsible for creating the Vienna Circle. It is important however to distinguish the institutional aspects of this society and the issues that were at the heart of the Philosophical Society, as it served as a philosophical discussion forum in which

75. C. Siegel, 1930, p. 48.

76. H. Gomperz, 1936, p. 311.

77. V. Kraft, 1953, p. 3; cf. also V. Kraft, 1952. 
were addressed various questions that were of interest to the Austrians and the Viennese at the time. We have barely scratched the surface of the rich content contained in some of the 600 conferences and discussion meetings that marked the history of the Society during the fifty years of its existence. In this respect, some of the writings mentioned in the beginning of this study give an idea of the scientific value and historical importance which this philosophical forum represented. In addition, as a forum that brought together the great Viennese intellectual figures, the Philosophical Society provides us with a specific framework, with its structure and its rules, as well as well as a philosophical perspective that differs from those adopted in the many writings on fin de siècle Vienna, which focus on topics such as the failure of liberalism, decadence, identity crisis or yet therapeutic nihilism, as exemplified by W. M. Johnston's classical book The Austrian $\operatorname{Mind}^{78}$. This perspective also allows us to avoid the pitfalls of a backward history of philosophy as advocated by certain historians of the Vienna Circle, who tend to see in the Austrian philosophical tradition nothing other than a Vienna Circle in the making or, to borrow Husserl's well-known expression, its secret aspiration.

With respect to the ideological dimension of this institution, our scope was limited to Reininger's efforts to subordinate the Philosophical Society to an organization, which at time, promoted the "great German philosophers". We showed that the reactions elicited by this decision demonstrate that the Philosophical Society was not considered as an organization simply amongst others by Austrians. As we have indicated at the beginning of this study, if we take into account the circumstances that led to the foundation of this organization and the significant involvement of Brentano and his students in the administration and activities of the Philosophical Society, it appears that this organization did not strictly represent for them a neutral discussion forum. The conferences delivered by Brentano in Vienna before his departure for Switzerland contain valuable information about the projects that he conducted for the Society, but also philosophy in general in Austria $^{79}$. But destiny decided otherwise and, as we have also indicated, it was Robert

78. W. Johnston, 1983. A number of texts brought together by S. Beller (2001) discuss the various perspectives endorsed by historians of turn-of-the-century Vienna.

79. But we also need to know that after his departure, in 1895, Brentano's name no longer appears in the Society's annual reports and, contrarily to most members of the Society, his death in 1917 was not mentioned in any of the annual reports, nor any of the meetings of the Society. We should note however 
Zimmerman who, due to his academic situation among other things, took matters into his own hands. A number of sources indicate that there were tangible tensions between Zimmerman and Brentano, particularly in an annual report published on the occasion of the $25^{\text {th }}$ anniversary of the Society, which reveals that the source of these conflicts lied in the monopoly of Herbart's philosophy in Austria since Count Leo Thun's reform and of which Zimmerman was the main representative since his arrival in Vienna:

Since the reform of high schools and higher education institutions in 1850, Herbartianism was the official philosophy in Austria as was Hegelianism in Prussia at the time. Nevertheless, in the decade during which our society was founded, such a monopoly became increasingly anachronistic. Directly in line with this transition phase, there were so to speak two poles, Zimmerman, on the one hand, Franz Brentano and his many students, on the other ${ }^{80}$.

This polarization revealed itself in many forms within the Philosophical Society, most notably in 1889 during a conference given by Zimmerman on Herbart's psychology, which Brentano criticizes at length in his correspondence with Zimmerman ${ }^{81}$.

But the sworn enemy of Brentano and his students in Vienna was the Bavarian philosopher Friedrich Jodl, who was president of the Philosophical Society between 1903 and 1912. Jodl is mainly known for his work in ethics, his edition of the works of Feuerbach as well as the founder of the Ethical Society ${ }^{82}$. He also made himself known during his presidency at the Philosophical Society for his involvement in the Klimt Affair, which was examined earlier, his well-known polemic with Boltzmann ${ }^{83}$ and his

that A. Kastil delivered three conferences on Brentano in 1934, 1936 and 1938. Brentano's correspondence shows however that he kept himself informed of the Philosophical Society's activities after 1895 and that he was aware of the controversy surrounding his succession in Vienna. Cf. Fisette, 2012 (forthcoming).

80. Jahresbericht, 1912-1913, p. 6.

81. R. Zimmermann, 1889; cf. Fisette, 2012 (forthcoming).

82. Cf. W. Börner, 1911.

83. This polemic occurred in 1905 during a conference delivered by Boltzmann on Schopenhauer in a meeting of the Society. The original title of Boltzmann's conference was "Proof that Schopenhauer is a Stupid, Ignorant Philophaster, Scribbling Nonsense and Dispensing Hollow Verbiage that Fundamentally and Forever Rots People's Brains". Blackmore (1995, p. 253) summarizes this polemic as follows: "In the discussion afterwards Jodl valiantly defended the great pessimist and regretted that Boltzmann had been hired to teach philosophy, since it had been under the false impression that he would bring physics and philosophy closer together. In fact, Jodl argued that if life is as painful as Schopenhauer maintained then suicide was legitimate as was using philosophy to justify such a negative act. Boltzmann replied that if Jodl wanted to commit suicide then he should do it, but that he could never prove it was rational. As is wellknown, Boltzmann himself committed suicide the next year, that is, in September 1906." We know through 
maneuvers against Brentano and his students. His situation is incidentally tied to Brentano's students: he obtains a position in Prague in 1884 as C. Stumpf's replacement and becomes the colleague of A. Marty and T. Masaryk, two other students of Brentano; afterwards he receives an appointment as Zimmerman's replacement in 1896 in Vienna, and he himself is replaced in Prague by another of Brentano's student, that is, C. von Ehrenfels. As pointed out by Höfler in his autobiography, at the time of his departure from Prague in 1896, Jodl made it his mission to eradicate what he called the "Brentanoids" from the Austrian planet and thus intensified his efforts to break the monopoly held by the students of Brentano in the Austrian universities. In his correspondence with Bolin and in a long letter addressed to Breuer, the anticlerical Jodl describes Brentano's students as a provincial clique made up of priests or former priests who promote a liberal theology ${ }^{84}$. Jodl increased his efforts within and outside the Philosophical Society to break what he also called the "Brentano system". Finally, we should note that Jodl could rely on other opponents of Brentano within the Society, particularly L. Müllner, A. Stöhr and mostly W. Jerusalem who intensified the attacks on Brentano $^{85}$.

Our examination of the Philosophical Society of the University of Vienna was limited to a few aspects of the relationship that we can establish between this organization and the Vienna Circle. Our ambition was simply to call attention to the significance of this institution within the history of philosophy in Austria, as Zimmermann, Brentano, Jodl, Reininger and Neurath all recognized in their own way. Many other aspects of this remarkable organization deserve an in-depth examination not only with respect to the Austrian philosophical tradition, but also regarding the many scientific disciplines that underwent astonishing developments during the 50 years of the Society's existence. For, as an organ of the Faculty of Philosophy and because of its interdisciplinary nature, the Philosophical Society was a privileged witness to the discussions that marked the evolution of disciplines such as psychiatry and

his correspondence with Brentano, with whom he was close during this period, that it was Brentano that convinced him to modify this title and to bring important changes to his text.

84. Cf. Gimpl, 1990, p. 46-47.

85. This is confirmed by W. Jerusalem (1925, p. 1-35) in a few passages of his autobiography, which were removed from the official version published by R. Schmidt in 1922. 
psychoanalysis (the numerous debates about sexuality, for example), zoology (the dispute over Darwinism represented one of the most important debates within the Society), physiology and physiological psychology (with Mach, Hering, a number of colleagues from the Department of Medicine, Brentano and most of his students), physics (debates on classical mechanics and the theory of relativity with Höfler and most of the members of the Department of Physics), economics, sociology, ethics, history of art, musicology, etc. This is why the Philosophical Society represents an important resource with respect to the study of what is commonly referred to as fin de siècle Vienna.

\section{Bibliography}

—. Jahresbericht der philosophischen Gesellschaft an der Universität zu Wien, Wien, Selbstverlag, 1888-1918.

—. Wissenschaftliche Beilage zum Jahresbericht der philosophischen Gesellschaft an der Universität zu Wien, Wien, Selbstverlag, 1902-1911.

_. Jahrbuch der philosophischen Gesellschaft an der Universität zu Wien, Wien, Selbstverlag, 1912-1916.

—. Wissenschaftliche Jahresberichte, Wien, Selbstverlag, 1926-1935.

—_. "Bericht", Kant-Studien, Bd. 32, 1927, p. 556.

- Wissenschaftliche Weltauffassung. Der Wiener Kreis, Wien, Artur Wolf Verlag, 1929.

Bahr, H. Gegen Klimt, Wien, J. Eisenstein and Co, 1903.

Beller, S. (ed.). Rethinking Vienna 1900, New York, Bergahn Books, 2001.

Bergmann, H. Das philosophische Werk Bernard Bolzanos, Halle, Niemeyer, 1909.

_. "Das philosophische Werke Bernard Bolzanos", Deutsche Arbeit, vol. VIII, 1908, p. 81-89.

Bettelheim, A. "Alfred Freiherr von Berger", Biographisches Jahrbuch und Deutscher Nekrolog, vol. 17, 1915, p. 191-200.

Blackmore, J. "Alois Höfler (1853-1922)”, in L. Albertazzi, D. Jacquette and R. Poli (eds.) The School of Alexius Meinong, Aldershot, Ashgate, 2001, p. 157-189. 
Blackmore, J. (ed.), Ludwig Boltzmann - His Later Life and Philosophy, 1900-1906, 2 volumes, Dordrecht, Kluwer, 1995.

Blackmore, J., R. Itagaki and S. Tanaka (eds.). Ernst Mach's Vienna - 1895-1930, Dordrecht, Kluwer, 2001a.

—. "Alois Höfler - Polymath", in Ernst Mach's Vienna - 1895-1930, Dordrecht, Kluwer, 2001b, p. 237-276.

Bolzano, B. Wissenschaftslehre, 4 Bde, Hrgb, von W. Schultz, Leipzig, F. Meiner, 1929.

—. Paradoxien des Unendlichen, Hrgb. von A. Höfler, mit Anmerkungen von H. Hahn, Leipzig, F. Meiner, 1920.

—. Wissenschaftslehre, Bd. I, Hrgb. von A. Höfler, Leipzig, F. Meiner, 1914.

Börner, W. Friedrich Jold, Stuttgart u. Berlin, Cotta, 1911.

Brentano, F. 1893. "Über die Zukunft der Philosophie", in Über die Zukunft der Philosophie, Hrgb. Von O. Kraus, Leipzig, Meiner, 1929, p. 1-48.

—. 1889. "Über den Begriff der Wahrheit", in Wahrheit und Evidenz, Hrgb. O. Kraus, Leipzig, F. Meiner, 1930, p. 3-29.

—. 1888. "Zur Methode der historischen Forschung auf philosophischem Gebiet", in Gechichte der Philosophie der Neuzeit, Hrgb. Von K. Hedwig, Hamburg, Meiner, 1987, p. 81-94.

Bühler, K. "Die Axiomatik der Sprachwissenschaft", Kant-Studien, Bd. 38, 1933, p. 1990.

—_. "Die Krise der Psychologie", Kant-Studien, Bd. 31, 1926, p. 455-526.

Coen, D. R. Vienna in the Age of Uncertainty. Science, Liberalism, and Private Life, Chicago, University of Chicago Press, 2007.

Cook, N. The Schenker Project: Culture, Race, and Music Theory in Fin-de-siècle Vienna, Oxford, Oxford University Press, 2007.

Exner, A. Über politische Bildung. Inaugurationsrede, Wien, Selbstverlag, 1891.

Fisette, D. "Brentano and the Philosophical Society of the University of Vienna", in D. Fisette and G. Fréchette (ed.), 2012 (forthcoming).

Fisette, D. and G. Fréchette (ed.) Themes from Brentano, Amsterdam, Rodopi, 2012 (forthcoming).

—. À l'école de Brentano, Paris, Vrin, 2007. 
Frank, P. Modern Science and its Philosophy, Cambridge, Harvard University Press, 1949.

—. Between Physics and Philosophy, Cambridge, Harvard University Press, 1941.

—. "Mechanismus oder Vitalismus? Versuch einer präzisen Formulierung der Fragestellung”, Annalen der Naturphilosophie, vol. 7, 1908, p. 393-409.

Gimpl, G. "Philosophie und Interesse? Bernard Bolzano im Tauziehen nationaler Inanspruch nahmen", Nachrichten FDÖP, vol. 9, 1998, p. 19-46.

Gimpl, G. Vernetzungen. Friedrich Jodl und sein Kampf um die Aufklärung, Oulu, 1990.

Gomperz, H. "Philosophy in Austria during the last Sixty Years", The Personalist, vol. 19, 1936, p. 307-311.

Haller, R. "The First Vienna Circle", in T. Uebel (ed.) Rediscovering the forgotten Vienna Circle, Dordrecht, Kluwer, 1991, p. 95-108.

—. "Wittgenstein and Austrian Philosophy", in J. C. Nyiri (ed.), Austrian Philosophy: Studies and Texts, München, Philosophia Verlag, 1981.

Hirschmüller, A. The Life and Work of Josef Breuer. Physiology and Psychoanalysis, New York, New York University Press, 1978.

Höfler, A. 1921. "Die Philosophie des Alois Höfler”, in R. Schmidt (Hrgb.) Die deutsche Philosophie der Gegenwart in Selbstdarstellungen, Bd. II, Leipzig, F. Meiner, 1921, p. 117-160.

—_. "Schopenhauer 1919-2020”, Schopenhauer-Jahrbuch, vol. 9, 1920, p. 85-147.

—. "Franz Brentano in Wien”, Süddeutsche Monatshefte, Bd. 4, 1917, p. 319-325.

—. Studien zur gegenwärtigen Philosophie der Mechanik. Als Nachwort zu: Kant's Metaphysische Anfangsgründe der Naturwissenschaft, Leipzig, 1900.

- (ed.) Vorreden und Einleitungen zu klassischen Werken der Mechanik: Galllei, Newton, D’Alembert, Lagrange, Kirchhoff, Hertz, Helmholtz. Übersetzt und herausgegeben von Mitgliedern der Philosophischen Gesellschaft, Leipzig, 1899.

—. 1894. Besprechung von Benno Kerry: "Über Anschauung und ihre psychische Verarbeitung" (Vierteljahresschrift für wissenschaftliche Philosophie, 18851891); E. G. Husserl: Philosophie der Arithmetik. Psychologische und logische Untersuchungen, Erster Band, (Halle-Saale, Pfeffer-Stricker, 1891); Chr. v. Ehrenfels: "Zur Philosophie der Mathematik" (Vierteljahrsschrift für 
wissenschaftliche Philosophie), Zeitschrift für Psychologie und Physiologie der Sinnesorgane, vol. 6, 1891, p. 44-58.

—. Worte der Erinnerung an Theodor Meynert und an sein Verhältnis zur Philosophischen Gesellschaft an der Universität zu Wien, Wien, Braumüller, 1892.

Höfler, A. \& Meinong, A. Philosophische Propädeutik. Logik. Wien, F. Tempsky, 1890.

Jerusalem, W. "Meine Wege und Ziele", Gedanken und Denker, Neue Folge, Wien, Braumüller, 1925, p. 1-35.

-. "Wilhelm Jerusalem. Meine Wege und Ziele", Hrgb. Von R. Schmidt, Die Philosophie der Gegenwart in Selbstdarstellung, Bd. III, Leipzig, Meiner, 1922, p. 53-98.

Johnston, W. N. The Austrian Mind: An Intellectual and Social History 1848-1938, Berkeley; Los Angeles, University of California Press, 1983.

Jodl, F. Vom Lebenswege, Gesammelte Vorträge und Aufsätze, Hrgb. Von W. Börner, Stuttgart u. Berlin, Cotta, 1916.

Kant, I. Metaphysische Anfangsgründe der Naturwissenschaft. Neu herausgegeben mit einem Nachworte von A. Höfler, Leipzig, 1900.

Keilhacker, M. Die Universitäts-Ausdehnungs-Problem in Deutschland und DeutschÖsterreich, Stuttgart, 1929.

Kerry, B. 1885-1891. "Über Anschauung und ihre psychische Verarbeitung", Vierteljahrsschrift für wissenschaftliche Philosophie, IX, 1885: 433-493; X, 1886: 419-467; XI, 1887 : 53-116; 4, XI, 1887: 249-307; 5 XIII 1889: 1-124, p. 392-419; XIV, 1890: 317-353; XV, 1891: 127-167.

Kraft, V. The Vienna Circle. The Origin of Neo-Positivism, New York, Philosophical Library, 1953.

__. "Franz Brentano", Wiener Zeitschrift für Philosophie, Psychologie, Pädagogik, Bd. IV, 1952, p. 1-8.

Kralik, B. and E. Schmid. Franz Serafin Exner und sein Kreis. Ein Beitrag zur Geschichte der Physik in Österreich, Wien, Verlag der österreichischen Akademie der Wissenschaften, 1982. 
Kreibig, J. C. "Bernard Bolzano. Eine Skizze aus der Geschichte der Philosophie in Österreich", Archiv für Geschichte der Philosophie, vol. 27, 1914, p. 273-287.

Leisching, E. Ein Leben für Kunst und Volksbildung. Eduard Leisching 1858-1938. Erinnerungen, hrsg. von Robert A. Kann und Peter Leisching, Wien, Verlag der Osterreichischen Akademie der Wissenschaften, 1978.

Mayerhofer, J. "Ernst Machs Berufung an die Wiener Universität 1895", Clio Medica, vol. 2, 1967, p. 47-55.

Menger, K. Unexplored Dimensions: Karl Menger on Economics and Philosophy (19231938), ed. by G. Becchio, Bingley, Emerald, 2009.

- "Einleitung" zu Hans Hahn Empirismus, Logik, Mathematik, Hrgb. B. McGuinness, Frankfurt a. M., Suhrkamp, 1988, p. 9-18.

Meister, R. 1938. "Die Geschichte der Philosophischen Gesellschaft an der Universitat Wien 1888-1938", in R. Reininger (Hrgb.) 50, Jahre Philosophische Gesellschaft an der Universität Wien 1888-1938, Wien.

Mulligan, K. "Grumbles and Quibbles from Mitteleuropa", Teorema, vol. XXX, 2011, p. 103-113.

_. "La place de la philosophie autrichienne", in K. Mulligan and J.-P. Cometti (eds.), La philosophie autrichienne, Paris, Vrin, 2001.

—. "The Essence of Language: Wittgenstein's Builders and Bühler's Bricks", Revue de métaphysique et de morale, vol. 2, 1997, p. 193-216.

Nawratil, K. Robert Reininger. Leben-Wirken-Persönlichkeit, Wien, Verlag der österreichischen Akademie der Wissenschaften, 1969.

Neurath, O. Le développement du Cercle de Vienne et l'avenir de l'empirisme logique, Paris, Hermann, 1935.

Reininger, R. “Ansprache”, Kant-Studien, vol. 35, 1930, p. 16-17.

_. "Kant und die deutsche Kultur", Volksbildung, Bd. V, 1924, p. 67-70.

Reynolds, J. Zur Aesthetik und Technik der bildenden Künste. Akademische Reden. Übersetzt und mit Einleitung, Anmerkungen, Register und Textvergleichung versehen von Dr. Eduard Leisching, Leipzig, 1893.

Rodlauer, H. Otto Weininger. Eros und Psyche, Wien, Verlag der österreichischen Akademie der Wissenschaften, 1990. 
Schlick, M. Gesamtausgabe, Bd. 6, 1, Die Wiener Zeit. Aufsätze, Beiträge, Rezensionen, 1926-1936, Hrgb. und eingeleitet von J. Friedl und H. Rutte, Wien, Springer, 2008.

Schorske, C. E. Fin-de-Siècle Vienna. Politics and Culture, New York, Alfred A. Knopf, 1980.

Siegel, C. "Philosophie", J. W. Nagl and al. (Hrgb.), Deutsch-Österreichische Literaturgeschichte, Bd. 3., Wien, C. Fromme, 1930, p. 17-48.

Smith, B. "The Neurath-Haller Thesis: Austria and the Rise of Scientific Philosophy", in K. Lehrer and J. C. Marek (eds.), Austrian Philosophy Past and Present, Dordrecht, Kluwer, 1996, p. 1-20.

Stadler, F. Studien zum Wiener Kreis. Ursprung, Entwicklung und Wirkung des Logischen Empirismus im Kontext, Frankfurt a. M., Suhrkamp, 1997.

Strobl, A. "Zu den Fakultätsbildern von Gustav Ktimt", Albertina-Studien, Bd. 2, 1964, p. 138-169.

Twardowski, K. "Funktionen und Gebilde", French translation: J. Plourde, "Fonctions et formations", in D. Fisette and G. Fréchette (ed.), À l'école de Brentano, Paris, Vrin, 2007, 1914, p. 343-385.

_. "Selfportrait", On Actions, Products and Other Topics in Philosophy, Amsterdam, Rodopi, 1999, p. 17-31.

Uebel, T. Otto Neurath und der erste Wiener Kreis. New York, Springer, 2000.

—. "Otto Neurath, the Vienna Circle and the Austrian Tradition", in A. O'Hear (ed.), German Philosophy since Kant, Cambridge: Cambridge University Press, 1999, p. 249-269.

Utitz, E. "Bernard Bolzanos Ästhetik”, Deutsche Arbeit, vol. VIII, 1908, p. 89-94.

Weininger, O. Geschlecht und Charakter. Eine prinzipielle Untersuchung, Wien, Braumüller, 1903.

Zimmermann, R. "Die Anfänge der mathematischen Psychologie in Wien", Wiener Zeitung, 1889, $\mathrm{n}^{\circ} 37$, p. 2-5; $\mathrm{n}^{\circ}$ 38, p. 2-4; $\mathrm{n}^{\circ}$ 39, p. 3-5.

_. "Philosophie und Philosophen in Österreich", Oesterreichisch-Ungarische Revue, Bd. 6, 1888-1889, p. 177-198, 259-272. 